\title{
Influence of Cryogenic Treatment on Microstructure and Properties Improvement of Die Steel
}

\author{
Shangtan Liu, Xiaochun Wu, Lei Shi, Yiwen Wu, Wei Qu \\ Material Science and Engineering School, Shanghai University, Shanghai, China \\ Email: Liushangtan2@163.com
}

Received 12 March 2015; accepted 13 September 2015; published 16 September 2015

Copyright (C) 2015 by authors and Scientific Research Publishing Inc.

This work is licensed under the Creative Commons Attribution International License (CC BY). http://creativecommons.org/licenses/by/4.0/

(c) (i) Open Access

\begin{abstract}
Cryogenic treatment has been increasingly applied to enhance the hardness, antiwear ability and fatigue performance of die steel. On the basis of reading a large number of research papers and references across the world, the author makes a detailed analysis and brief summary of the influence of cryogenic treatment on microstructure after quenching process or quenching plus tempering process, on first and second carbides, on content of retained austenite, on surface hardness, on mechanical properties and antiwear ability of die steels. It's proved that cryogenic treatment on die steel significantly improves its hardness, antiwear capacity and service life. It's the cryogenic process to make die steel have higher hardness, better antiwear ability, better ductility and longer service life because cryogenic process actually has a good influence on die steel of its microstructure, retained austenite volume and amount and size of the second carbide.
\end{abstract}

\section{Keywords}

Die Steel, Cryogenic Treatment, Retained Austenite, The Second Carbide, Antiwear Ability

\section{Introduction}

It's called as ordinary cryogenic treatment when materials are generally cooled lower than zero degree Celsius, say $0^{\circ} \mathrm{C}$ to $-130^{\circ} \mathrm{C}$, and stay for a period. But it's called as deep cryogenic treatment if the temperature is even lower, say $-130^{\circ} \mathrm{C}$ to $-196^{\circ} \mathrm{C}$. Deep cryogenic treatment is usually called super low temperature treatment.

\section{Cryogenic Treatment's Influence on Microstructure}

It's [1] been found that the antiwear ability can be greatly improved if die steel is cooled down to $-130^{\circ} \mathrm{C}$ or

How to cite this paper: Liu, S.T., Wu, X.C., Shi, L., Wu, Y.W. and Qu, W. (2015) Influence of Cryogenic Treatment on Microstructure and Properties Improvement of Die Steel. Journal of Materials Science and Chemical Engineering, 3, 37-46.

http://dx.doi.org/10.4236/msce.2015.39005 
even to $-196^{\circ} \mathrm{C}$ after its quenching. It is because most proportion of retained austenite is transformed to martensite which has a higher hardness and a better antiwear capacity than that of austenite. And some martensite even decomposes to $\varepsilon$ carbide which is as thin as nano-level article and is also conducive to improvement of antiwear ability after the die steel is tempered.

When X30CrMoN15-1 steel is quenched at $1200^{\circ} \mathrm{C}$ for 2 hours in a argon protection furnace [2], retained austenite is observed by optical microscope besides martensite and carbide (see Figure 1(b), marked as A). But when the quenching temperature is lowered to $1000^{\circ} \mathrm{C}$ or $900^{\circ} \mathrm{C}$, the retained austenite no longer exists (see Figure 2).

Shaohong Li also gets a result concerning the influence of cryogenic treatment on retained austenite volumes and widths of martensite laths [3] (see Table 1). Table 1 expresses that the retained austenite contents is significantly reduced by cryogenic treatment, with $16.9 \%$ of retained austenite content at the original quenching state, $4.1 \%$ of it after the first cryogenic treatment and $2.5 \%$ of it after the second cryogenic treatment.

O. N. Mohanty [4], R. E. Reed-Hill [5], D. V. Edmonds, K. He, F. C. Rizzo [6] and J. Speer, D. K. Matlock [7]

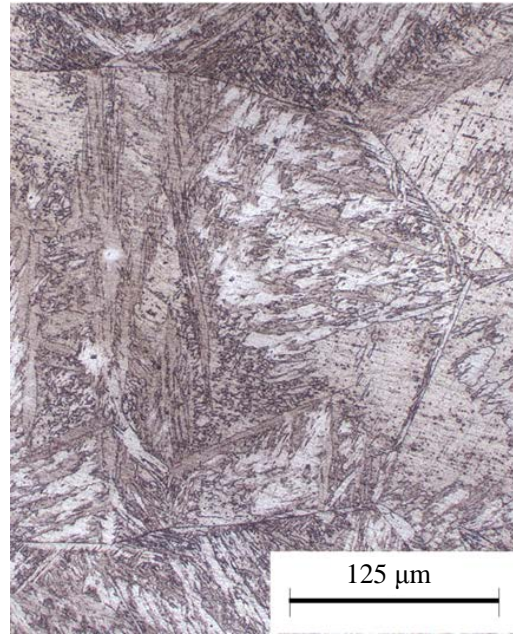

(a)

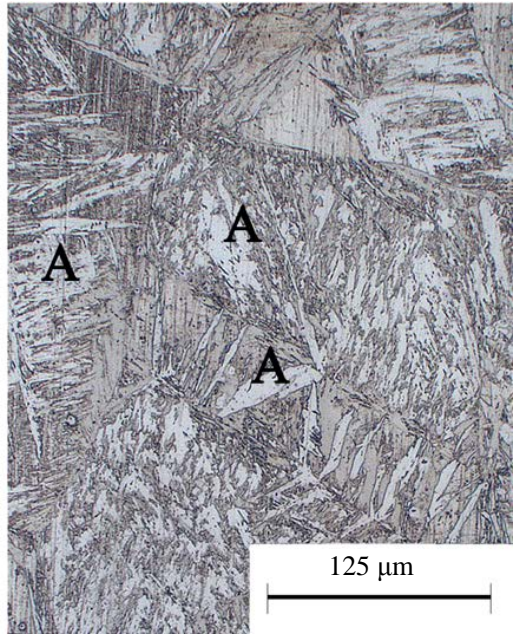

(b)

Figure 1. Quenching microstructure of 30CrMoN15-1: martensite + carbide + retained austenite. (a) Quenching in ethylene glycol at $1200^{\circ} \mathrm{C}$; (b) Quenching in air at $1200^{\circ} \mathrm{C}$.

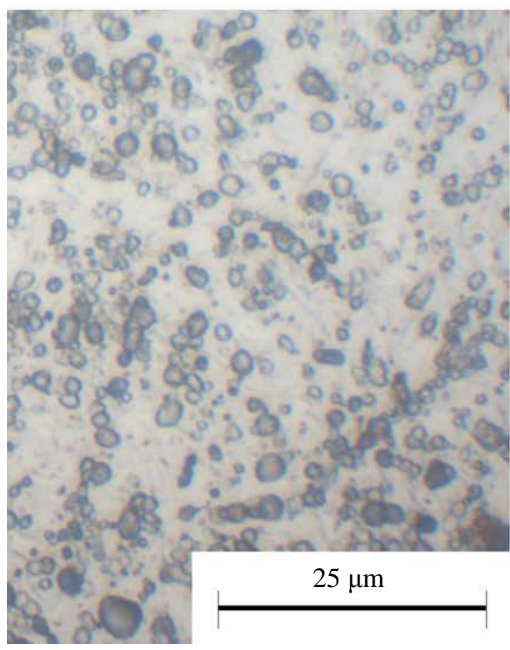

(a)

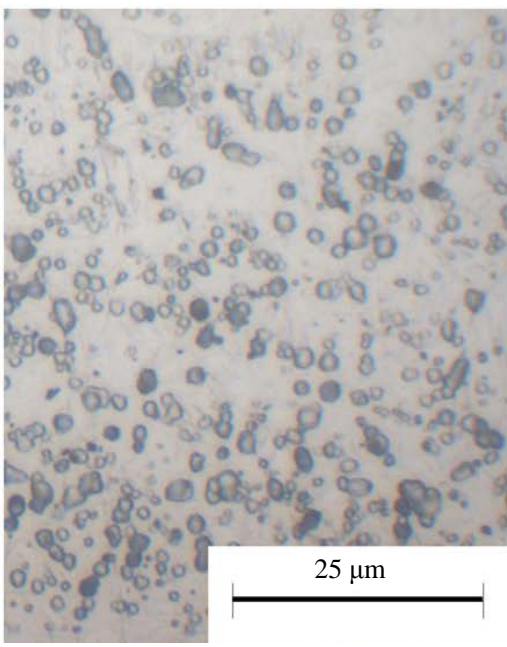

(b)

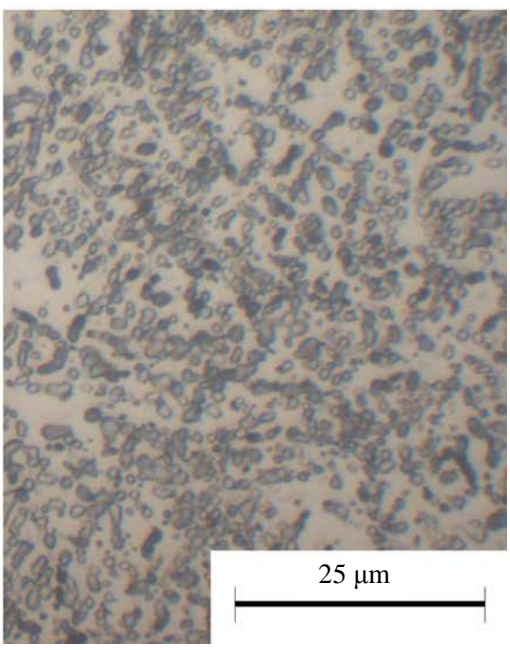

(c)

Figure 2. Quenching microstructure of 30CrMoN15-1: martensite + carbide. (a) Water quenching at $1000^{\circ} \mathrm{C}$; (b) Water quenching at $900^{\circ} \mathrm{C}$; (c) Air quenching at $1000^{\circ} \mathrm{C}$. 
give full theoretical explanations on how cryogenic treatment reducing the content of retained austenite, facilitating more second carbide to precipitate and increasing the stability of retained austenite so as to improve the antiwear ability and gain a longer service lifetime.

The TEM morphonology [3] of specimens treated as in Table 1 has been showed in Figure 3. Twice cryogenic process makes the martensite laths become thinner than once cryogenic process does, with its width changing from $255 \mathrm{~nm}$ for once cryogenic treatment to 60 - $80 \mathrm{~nm}$ for twice cryogenic treatment.

\section{Cryogenic Treatment's Influence on Mechanical Properties}

Das D, Dutta AK, Ray KK [8] [9] contribute the D2 antiwear ability improvement to the scattered distribution of second carbide occurring in case cryogenic treatment.

The austenitizing temperatures have a great influence on retained austenite content and hardness [2] which is displayed in Figure 4 when the samples are just quenched without a cryogenic treatment. An obvious drop in

Table 1. Influence of cryogenic treatment on retained austenite volumes and widths of martensite laths.

\begin{tabular}{|c|c|c|c|c|c|c|c|}
\hline $\begin{array}{c}\text { Heat } \\
\text { treatment } \\
\text { No. }\end{array}$ & $\begin{array}{c}\text { Quenching } \\
\text { temperature, } \\
{ }^{\circ} \mathrm{C}\end{array}$ & $\begin{array}{c}\text { The first } \\
\text { cryogenic } \\
\text { treatment, QC }\end{array}$ & $\begin{array}{l}\text { The first } \\
\text { tempering, } \\
\text { QCT }\end{array}$ & $\begin{array}{l}\text { The second } \\
\text { cryogenic } \\
\text { treatment, QCTC }\end{array}$ & $\begin{array}{l}\text { The second } \\
\text { tempering, } \\
\text { QCTCT }\end{array}$ & $\begin{array}{c}\text { Volume } \\
\text { percentage of } \\
\text { retained austenite }\end{array}$ & $\begin{array}{l}\text { Widths of } \\
\text { martensite } \\
\text { laths, mm }\end{array}$ \\
\hline Quenching & $1040^{\circ} \mathrm{C} / 1 \mathrm{~h}$ & & & & & 16.9 & - \\
\hline $\mathrm{C}$ & $1040^{\circ} \mathrm{C} / 1 \mathrm{~h}$ & $-75^{\circ} \mathrm{C} / 2 \mathrm{~h}$ & & & & 4.1 & 255 \\
\hline $\mathrm{D}$ & $1040^{\circ} \mathrm{C} / 1 \mathrm{~h}$ & $-75^{\circ} \mathrm{C} / 2 \mathrm{~h}$ & $510^{\circ} \mathrm{C} / 2 \mathrm{~h}$ & & & 3.3 & 200 \\
\hline $\mathrm{E}$ & $1040^{\circ} \mathrm{C} / 1 \mathrm{~h}$ & $-75^{\circ} \mathrm{C} / 2 \mathrm{~h}$ & $510^{\circ} \mathrm{C} / 2 \mathrm{~h}$ & $-75^{\circ} \mathrm{C} / 2 \mathrm{~h}$ & & 2.7 & 76 \\
\hline $\mathrm{F}$ & $1040^{\circ} \mathrm{C} / 1 \mathrm{~h}$ & $-75^{\circ} \mathrm{C} / 2 \mathrm{~h}$ & $510^{\circ} \mathrm{C} / 2 \mathrm{~h}$ & $-75^{\circ} \mathrm{C} / 2 \mathrm{~h}$ & $510^{\circ} \mathrm{C} / 2 \mathrm{~h}$ & 2.5 & 66 \\
\hline
\end{tabular}
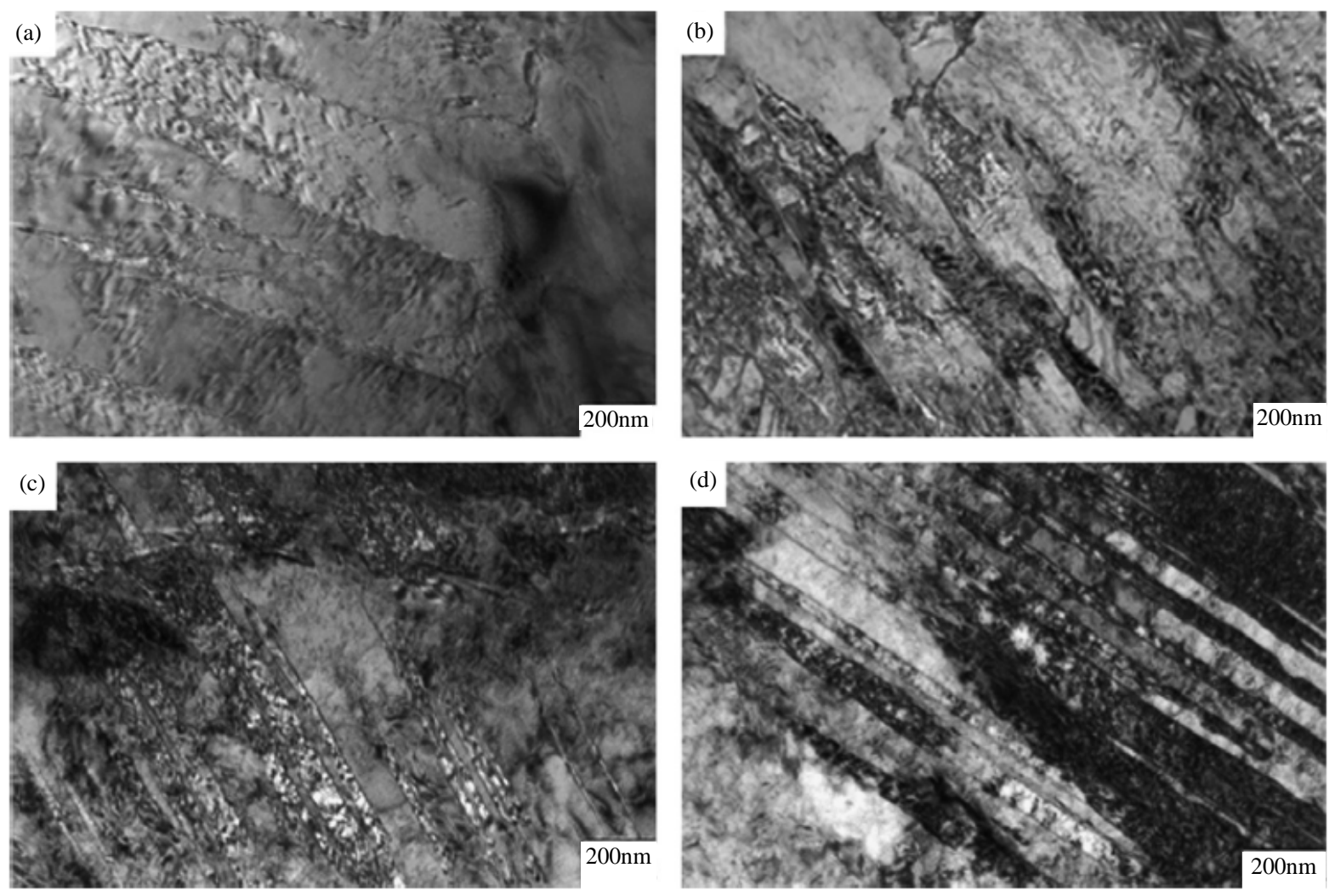

Figure 3. TEM morphology of specimens at different cryogenic treatment. (a) Treatment C; (b) Treatment D; (c) Treatment E; (d) Treatment F. 
hardness is seen when the austenization temperatures exceed $1000^{\circ} \mathrm{C}$ or even higher, with the highest hardness HRC 56 occurring at $1000^{\circ} \mathrm{C}$ and the lowest hardness HRC 33 at $1200^{\circ} \mathrm{C}$. But the retained austenite contents increase steadily while the austenitizing temperatures climb.

However the hardness maintains constant between HRC 54 and HRC 56 even the austenitizing temperature ranges from $900^{\circ} \mathrm{C}$ to $1200^{\circ} \mathrm{C}$ if the specimens are $24 \mathrm{~h}$ permanence at $-196^{\circ} \mathrm{C}$ just after the quenching process (see Figure 5).

The influences [2] of deep cryogenic treatment, which is arranged between quenching and tempering, on hardness and retained austenite content of X30CrMoN15-1 are displayed by Figure 6 (quenching at $1030^{\circ} \mathrm{C}$ ) and Figure 7 (quenching at $1150^{\circ} \mathrm{C}$ ). The cryogenic temperature is at $-196^{\circ} \mathrm{C}$ with maintaining period of 24 hours. When quenching at $1030^{\circ} \mathrm{C}$, hardness sees an increase of 10 to $11 \mathrm{HRC}$ after tempering in case of an additional $-196^{\circ} \mathrm{C}$ cryogenic treatment. The second hardening effect is more obvious in case of cryogenic treatment,

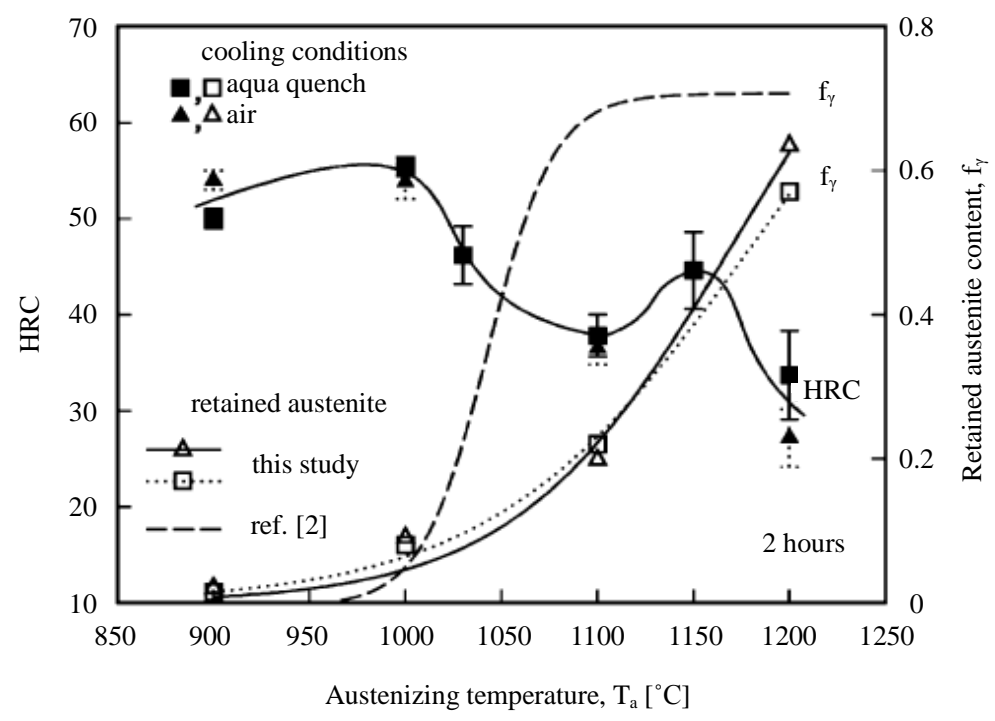

Figure 4. An obvious drop of hardness of X30CrMoN15-1 after the austenitizing temperature exceeds $1000^{\circ} \mathrm{C}$.

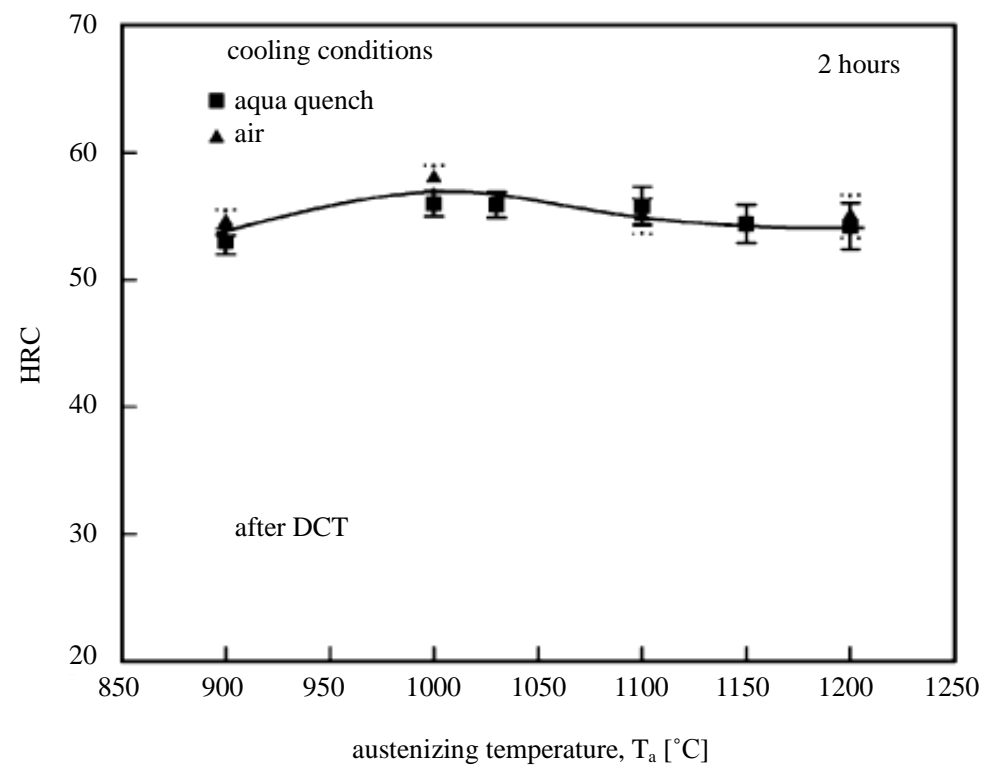

Figure 5. Hardness of X30CrMoN15-1 maintains constant when a deep cryogenic treatment follows after quenching. 


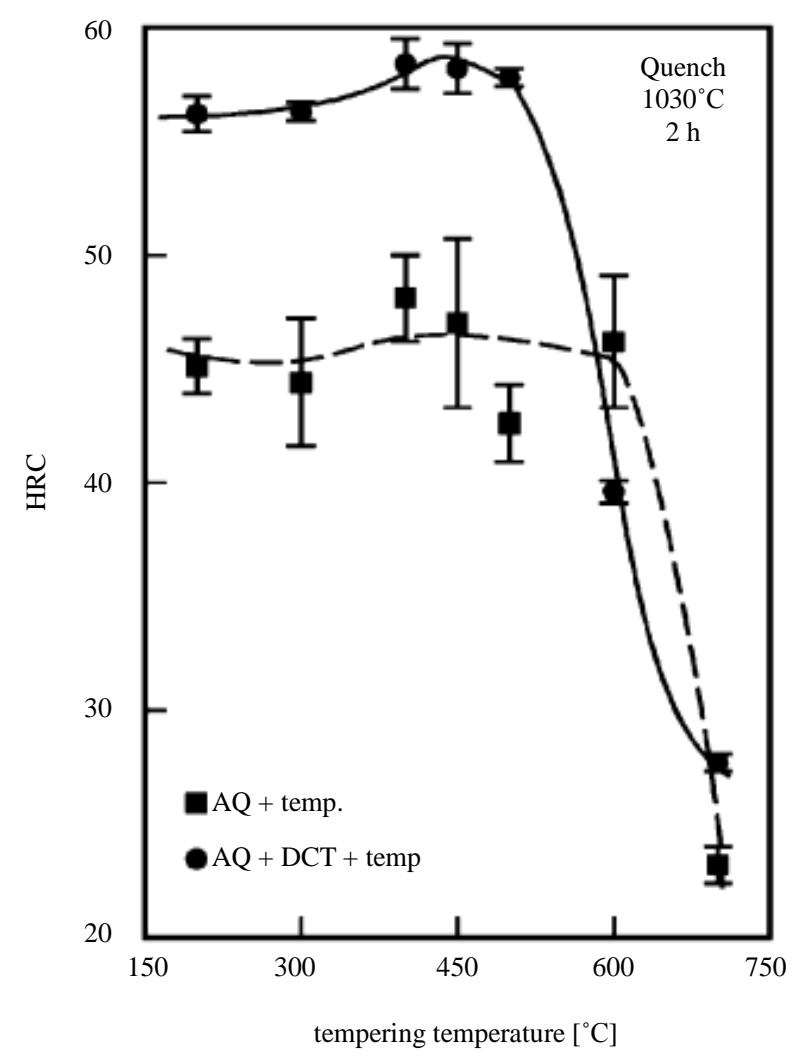

Figure 6. Influence of deep cryogenic treatment on hardness of X30CrMoN15-1 (quenching at $1030^{\circ} \mathrm{C}$ ).

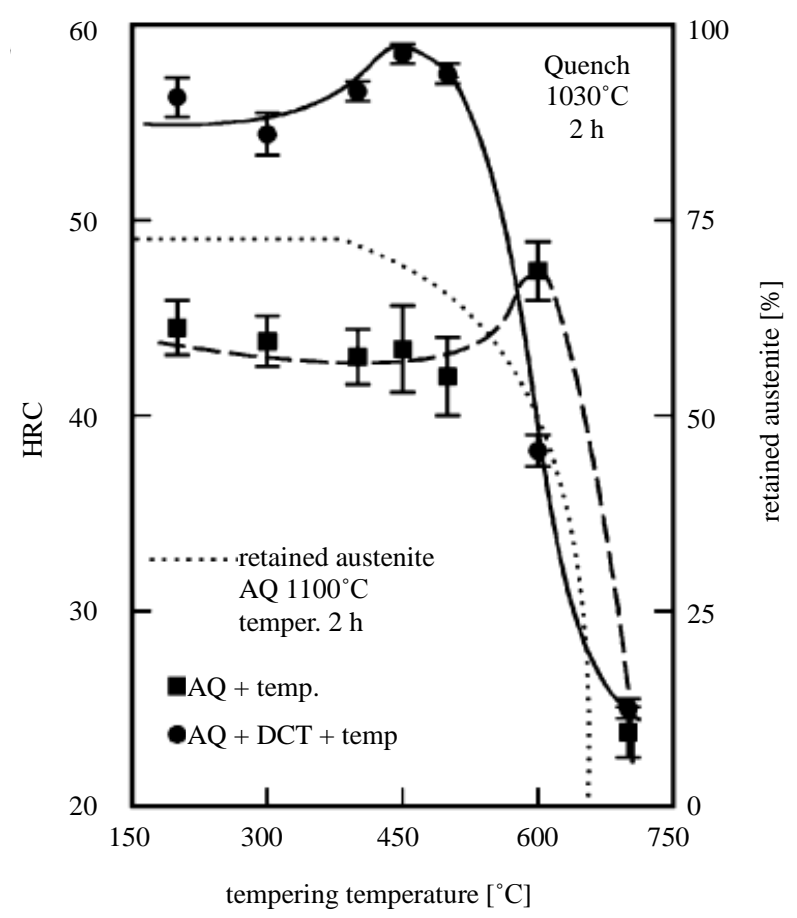

Figure 7. Influence of deep cryogenic treatment on hardness of X30CrMoN15-1 (quenching at $1150^{\circ} \mathrm{C}$ ). 
which facilitates the retained austenite to change to martensite and is conducive to the precipitation of large amount of second fine carbides and carbonitrides from the martensite oversaturated by carbon and nitrogen. Similarly when quenching at $1150^{\circ} \mathrm{C}$, an hardness rise of 11-14 HRC can be obtained.

A simple model is established where the role of martensite, retained austenite, carbide and carbonitride is considered as a whole to set up a function relevance between hardness and quenching temperature. The model is pretty good to predict the volume of martensite, retained austenite, carbide and carbonitride. As a result, the martensite content, carbide as well as carbonitride content reduce with the increasingly higher quenching temperature, but the retained austenite content significantly ascended (see Figure 8).

Indeed the mechanical properties of 1.2542 [10] can also be improved through deep cryogenic treatment. In reality, the most exciting point is that the elongation also is raised by $12 \%-35 \%$ while the tensile strength and hardness are improved by $32 \%-36 \%$ and $12 \%$ respectively when a cryogenic treatment at $-196^{\circ} \mathrm{C}$ with maintaining periods of 24 - 48 hours after quenching, and tempering at $200^{\circ} \mathrm{C}$ is implemented.

\section{Influence of Cryogenic Treatment on Second Carbide Sizes and Volumes in Die Steel}

It is the large amount of spherical fine second carbide particle precipitated during deep cryogenic treatment that effectively improves the service lifetime and size stability of die steel [11]-[15].

It's been discovered [8] in D2 die steel that the deep cryogenic treatment increases the small second carbide (SSCs) volume amount by $11.4 \%$, increases its distribution density by $250 \%$, decreases its average size by $34 \%$. The deep cryogenic treatment also increases the large second carbide volume amount by $22.3 \%$, increase its distribution density by $100 \%$, decrease its average size by $23 \%$ (see Figure 9 and Figure 10).

The finer spheric second carbide particles has been observed [2] clearly through TEM if 1.2542 die steel suffered deep cryogenic treatment. The average diameter of it is $65 \mathrm{~nm}$ with soaking temperature $-196^{\circ} \mathrm{C}$ and tempering at $200^{\circ} \mathrm{C}$ (see Figure 11).

\section{Influence of Cryogenic Treatment on Antiwear Ability}

It's been reported [16]-[18] that deep cryogenic treatment definitely greatly improves the antiwear ability of die steel although it does not increase hardness much. Because retained austenite is soft and unstable and easy to change into brittle and hard martensite as well as a change in size, it has a negative influence on antiwear ability in die steel [19].

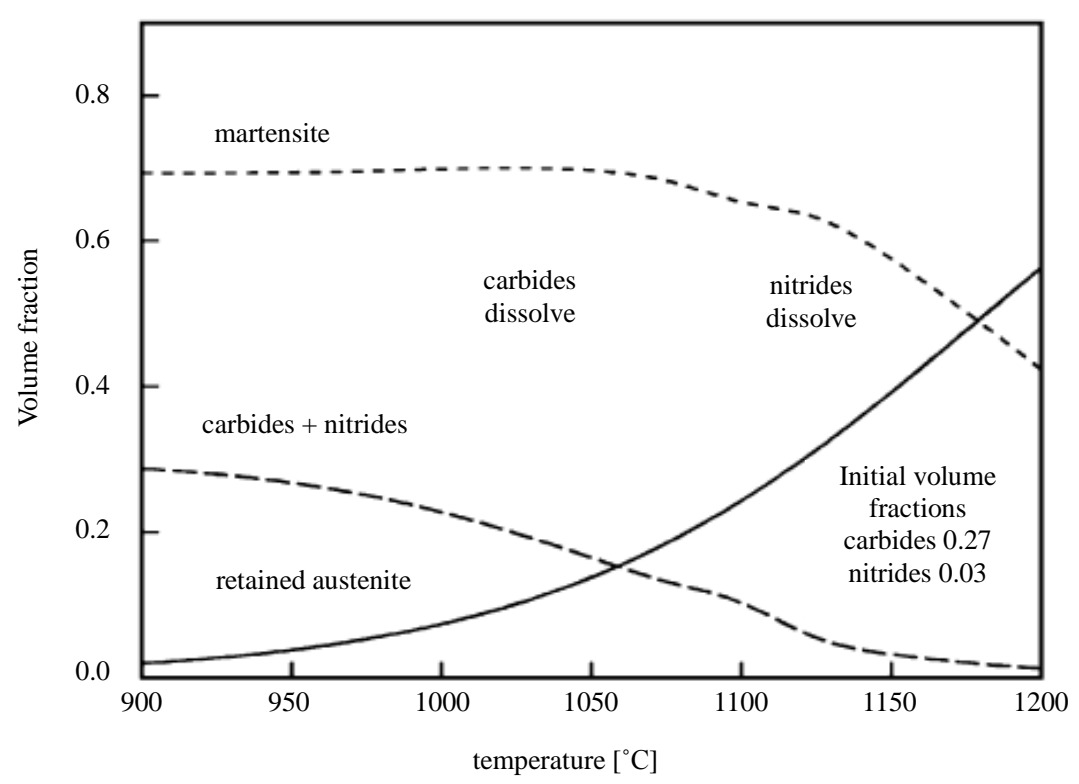

Figure 8. Function relevance between microstructure ingredients of X30CrMoN15-1 and quenching temperatures with deep cryogenic treatment following after quenching. 

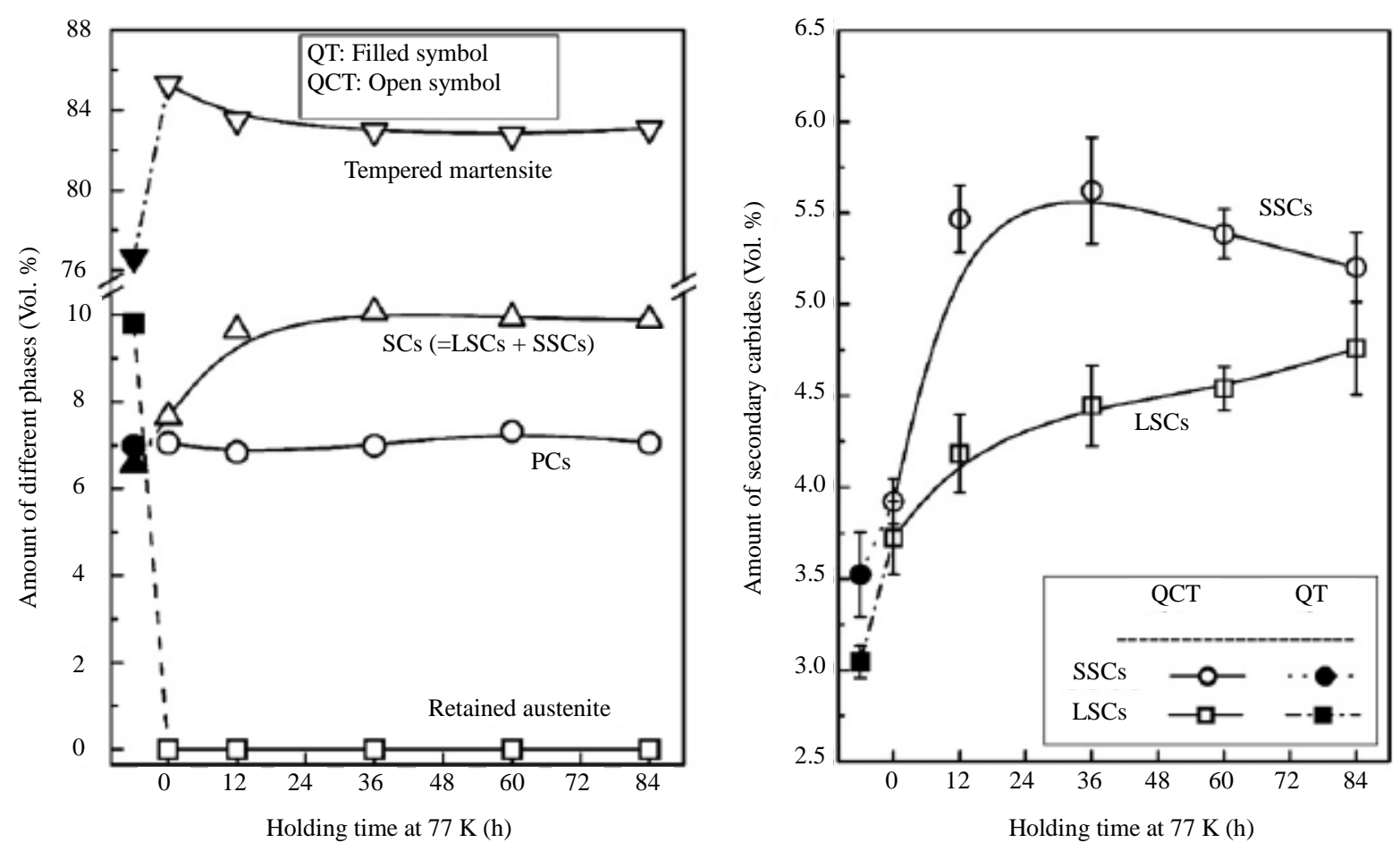

Figure 9. Deep cryogenic treatment influences amount of the small second carbide and large second carbide.
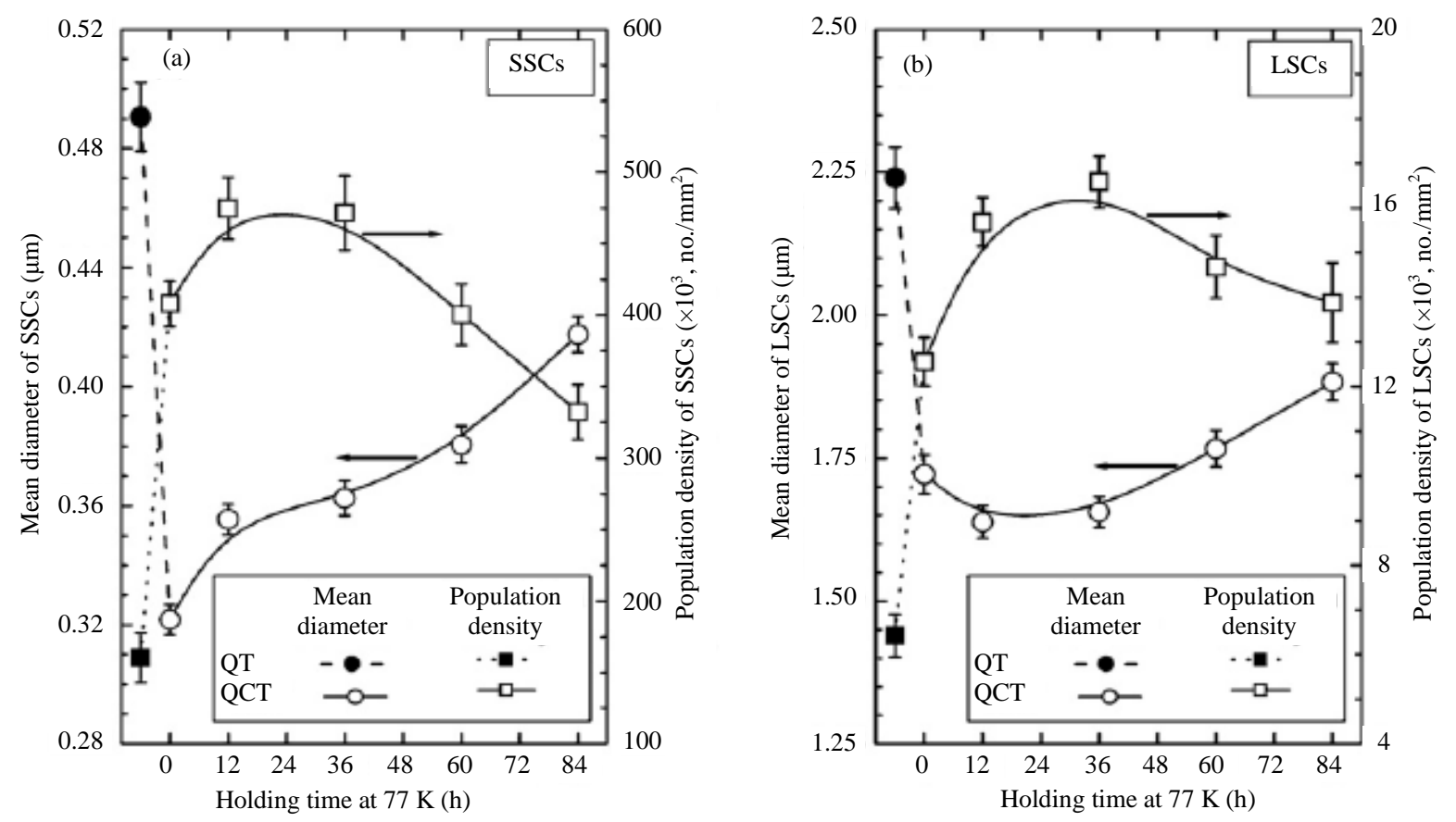

Figure 10. Deep cryogenic treatment influences the sizes and distribution density of the small second carbide and large second carbide.

Influence of cryogenic treatment on antiwear ability in D2 die steel is conducted and the interaction between sliding distance and accumulative wear loss volume is displayed in Figure 12 [20] [21]. The accumulative wear loss grows rapidly with the die steel in a state of traditional quenching and tempering but it drops dramatically in the case of the die steel experiencing a cryogenic treatment between quenching and tempering. 


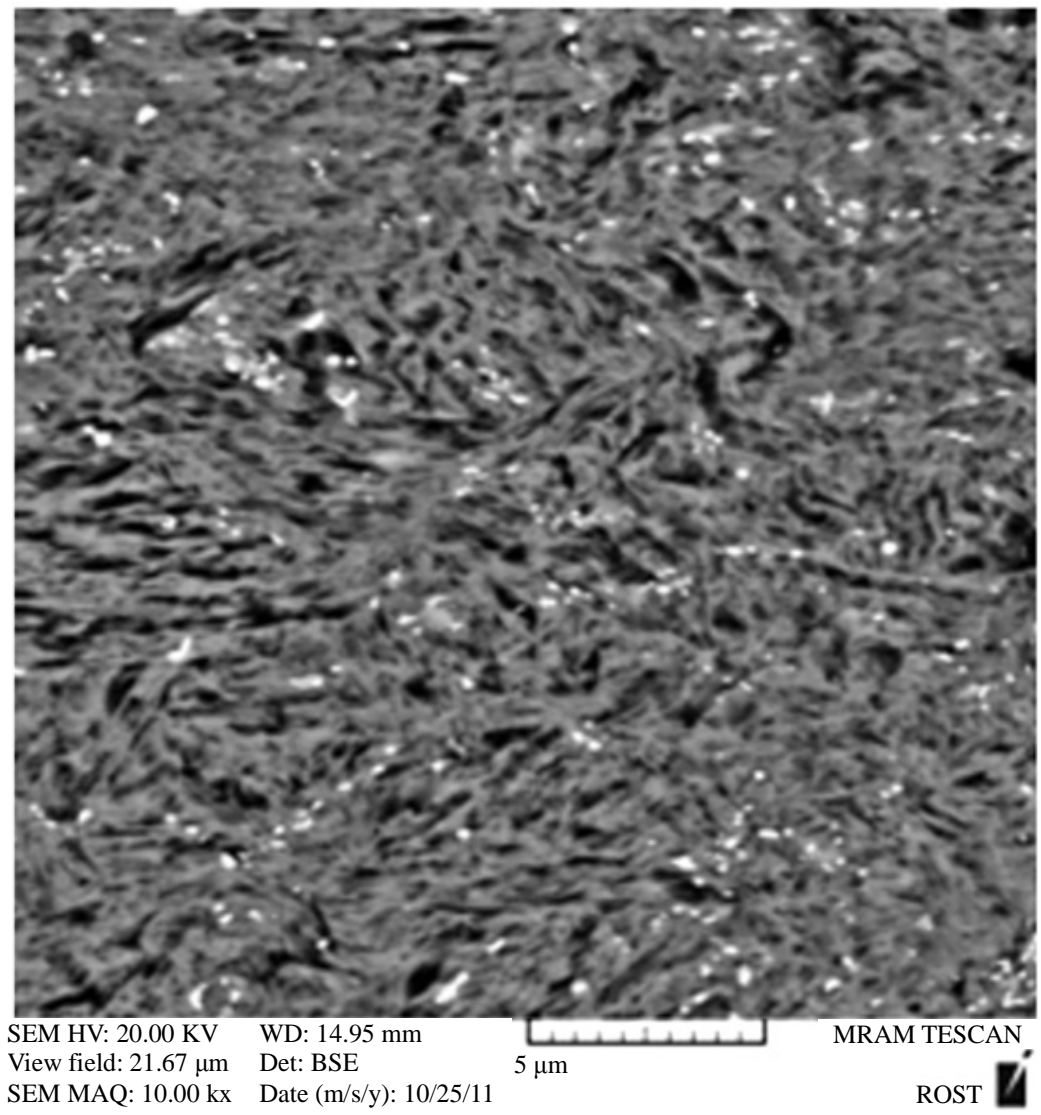

Figure 11. The finer spheric second carbide particles observed in deep cryogenic treatment of 1.2542.
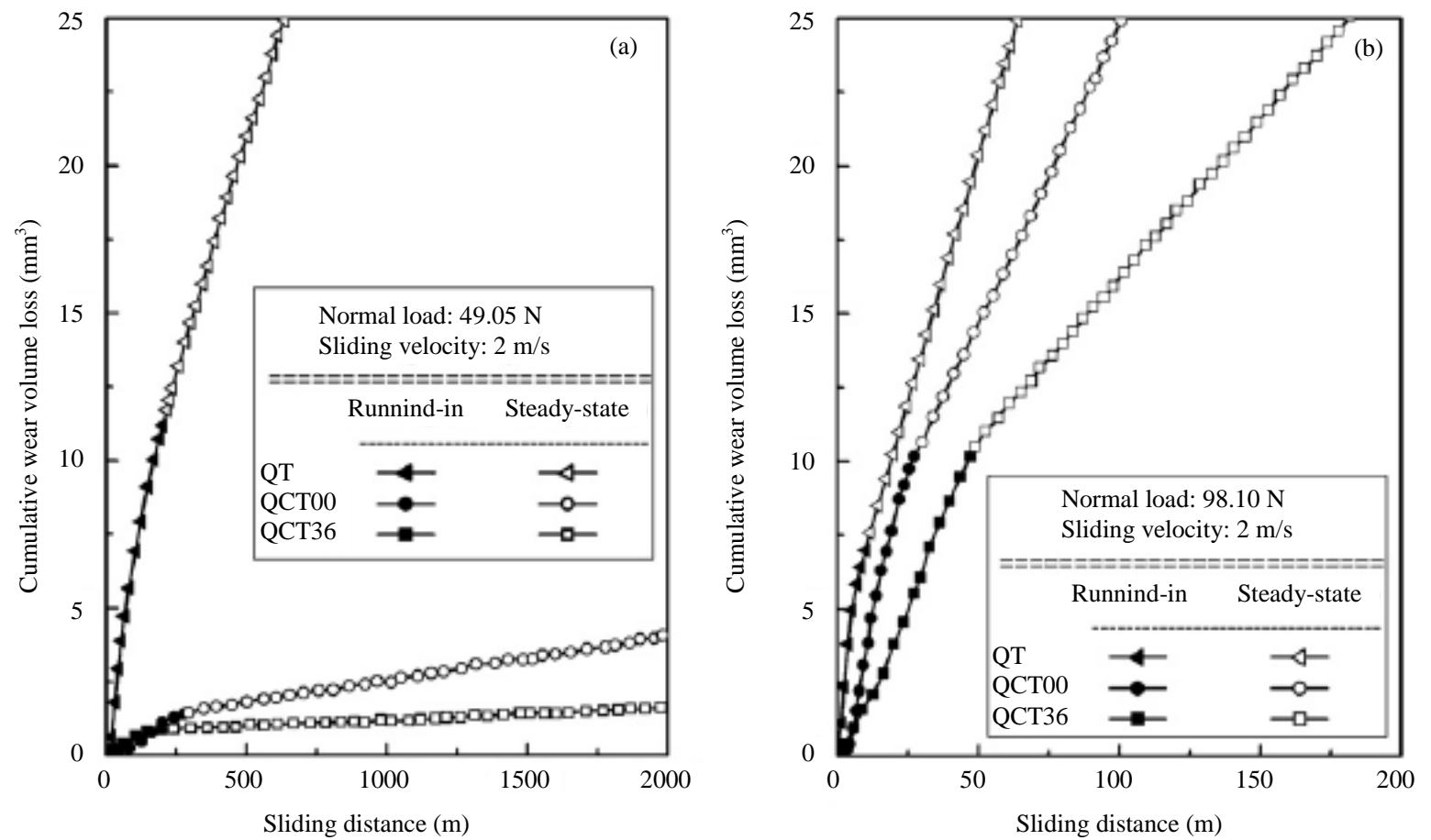

Figure 12. The correlation between sliding distance and accumulative wear volume. 

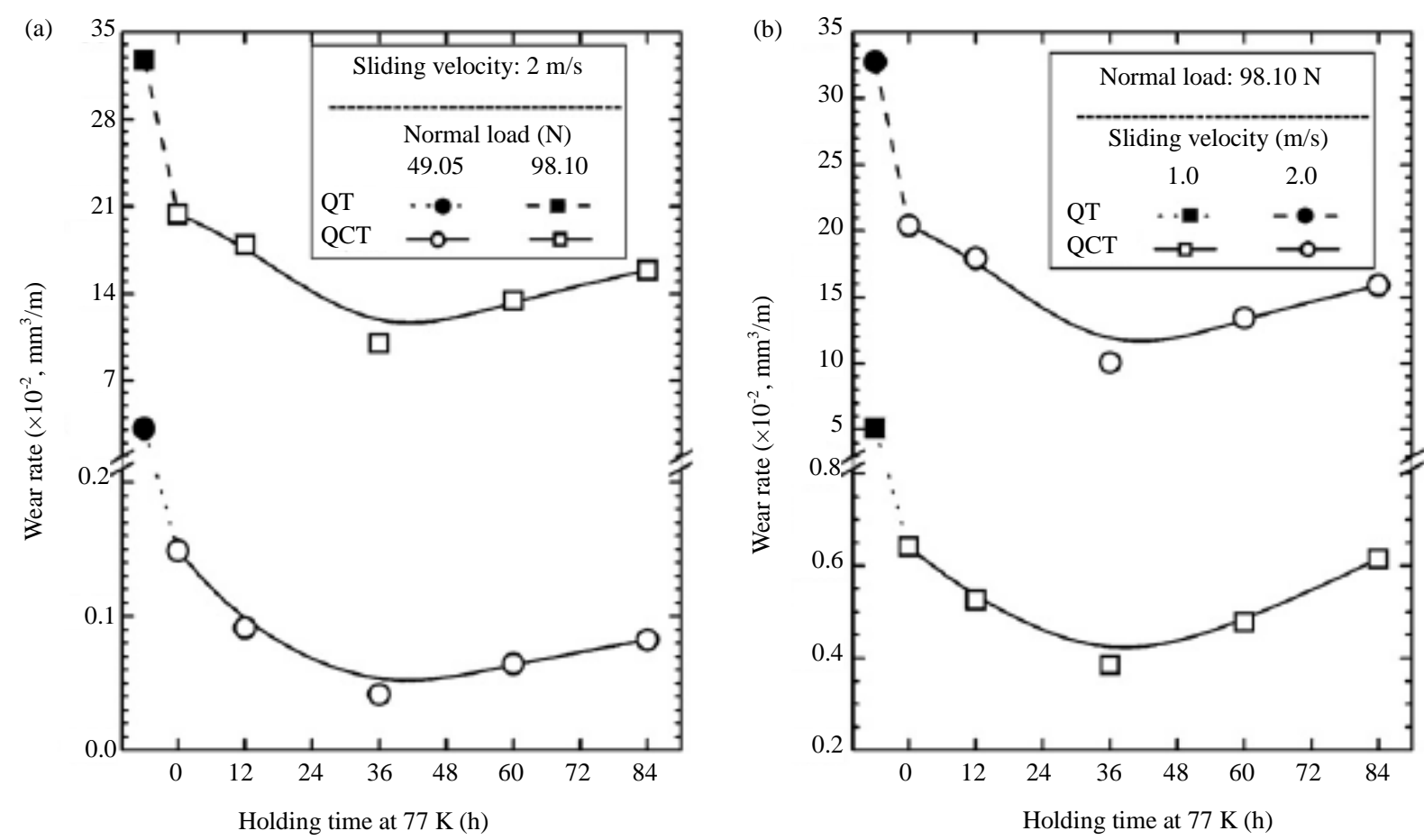

Figure 13. A remarkable benefit on antiwear ability of D2 die steel through cryogenic treatment.

A remarkable benefit on antiwear ability of $\mathrm{D} 2$ die steel can be achieved through cryogenic treatment as showed in Figure 13. In case of $\mathrm{FN}=98.1 \mathrm{~N}, \mathrm{Vs}=1 \mathrm{~m} / \mathrm{s}$ and $\mathrm{FN}=49.05 \mathrm{~N}, \mathrm{Vs}=2 \mathrm{~m} / \mathrm{s}$, the antiwear ability rises as high as 13.2 times and 76.2 times respectively if there is a cryogenic treatment compared to there isn't.

\section{Influence of Cryogenic Treatment on Retained Austenite Content}

Study reveals that it is the cryogenic treatment that reduces the volume of retained austenite to improve the size stability and antiwear ability [3]. The large amount of retained austenite $16.9 \%$ is tested through X-ray diffraction when the sample just is quenched at $1040^{\circ} \mathrm{C}$ with maintenance period of 1 hour. But it is only $4.1 \%$ if the sample continues to be cooled down to $-75^{\circ} \mathrm{C}$ for 2 hours and it continues to drop to $2.5 \%$ when the sample experiences twice of cryogenic treatment and twice of tempering.

\section{Conclusions}

1) Cryogenic treatment increases the mechanical properties, hardness, antiwear ability and service lifetime significantly because it can facilitate the retained austenite to transform to martensite, reduce the volume of retained austenite and improve the stability of retained austenite as well as precipitate more and finer second carbide or carbonitride.

2) Cryogenic treatment helps to reduce the hardness fluctuation range with the variation of quenching temperature as well as increase hardness up to 10 - 14 HRC.

3) It is found that the cryogenic process also reduces the width of martensite laths.

4) Various technological parameters on quenching, cryogenic and tempering process should be adopted for various steel grades to gain best mechanical properties, antiwear abilities and longest service lifetime.

\section{References}

[1] Stratton, P.F. (2007) Optimizing Nano-Carbide Precipitation in Tools Steels. Materials Science and Engineering: A, 449-451, 809-812. http://dx.doi.org/10.1016/j.msea.2006.01.162

[2] El Mehtedi, M. and Ricci, P. (2012) Analysis of the Effect of Deep Cryogenic Treatment on the Hardness and Microstructure of X30 CrMoN 151 Steel. Materials and Design, 33, 136-144. 
http://dx.doi.org/10.1016/j.matdes.2011.07.030

[3] Li, S.H. and Yuan, X.H. (2014) Effects of Heat Treatment Influencing Factors on Microstructure and Mechanical Properties of a Low-Carbon Martensitic Stainless Bearing Steel. Materials Science and Engineering: A, 605, 229-235. http://dx.doi.org/10.1016/j.msea.2014.03.061

[4] Mohanty, O.N. (1995) On the Stabilization of Retained Austenite: Mechanism and Kinetics. Materials Science and Engineering: B, 32, 267-278. http://dx.doi.org/10.1016/0921-5107(95)03017-4

[5] Reed-Hill, R.E. and Abbaschian, R. (1992) Physical Metallurgy Principles. 3rd Edition, PWS-KENT, Boston.

[6] Edmonds, D.V., He, K., Rizzo, F.C., DeCooman, B.C., Matlock, D.K. and Speer, J.G. (2006) Quenching and Partitioning Martensite-A Novel Steel Heat Treatment. Materials Science and Engineering: A, 438-440, 25-34. http://dx.doi.org/10.1016/j.msea.2006.02.133

[7] Speer, J., Matlock, D.K., DeCooman, B.C. and Schroth, J.G. (2003) Carbon Partitioning into Austenite after Martensite Transformation. Acta Materialia, 51, 2611-2622. http://dx.doi.org/10.1016/S1359-6454(03)00059-4

[8] Das, D., Dutta, A.K. and Ray, K.K. (2009) Influence of Varied Cryotreatment on the Wear Behaviour of AISI D2 Steel. Wear, 266, 297-309. http://dx.doi.org/10.1016/j.wear.2008.07.001

[9] Das, D., Ray, K.K. and Dutta, A.K. (2009) Influence of Temperature of Sub-Zero Treatments on the Wear Behaviour of Die Steel. Wear, 267, 1361-1370. http://dx.doi.org/10.1016/j.wear.2008.11.029

[10] Farhani, F. and Niaki, K.S. (2012) Study of Effects of Deep Cryotreatment on Mechanical Properties of 1.2542 Tool Steel. Materials and Design, 42, 279-288. http://dx.doi.org/10.1016/j.matdes.2012.05.059

[11] Li, S.H., Deng, L.H., Wu, X.C., Min, Y.A. and Wang, H.B. (2010) Influence of Deep Cryogenic Treatment on Microstructure and Evaluation by Internal Friction of a Tool Steel. Cryogenics, 50, 754-758. http://dx.doi.org/10.1016/j.cryogenics.2010.09.002

[12] Li, S.H., Min, N., Deng, L.H., Wu, X.C., Min, Y.A. and Wang, H.B. (2011) Influence of Deep Cryogenic Treatment on Internal Friction Behavior in the Process of Tempering. Materials Science and Engineering: A, 528, 1247-1250. http://dx.doi.org/10.1016/j.msea.2010.10.012

[13] Li, S.H., Min, N., Li, J.W., Wu, X.C., Li, C.H. and Tang, L.L. (2013) Experimental Verification of Segregation of Carbon and Precipitation of Carbides Due to Deep Cryogenic Treatment for Tool Steel by Internal Friction Method. Materials Science and Engineering: A, 575, 51-60. http://dx.doi.org/10.1016/j.msea.2013.03.070

[14] Li, S.H., Deng, L.H., Wu, X.C., Wang, H.B., Min, Y.A. and Min, N. (2010) Effect of Deep Cryogenic Treatment on Internal Friction Behaviors of Cold Work Die Steel and Their Experimental Explanation by Coupling Model. Materials Science and Engineering: A, 527, 7950-7954. http://dx.doi.org/10.1016/j.msea.2010.08.086

[15] Li, S.H., Deng, L.H., Wu, X.C., Min, Y.A. and Wang, H.B. (2010) Influence of Deep Cryogenic Treatment on Microstructure and Evaluation by Internal Friction of a Tool Steel. Cryogenics, 50, 754-758. http://dx.doi.org/10.1016/j.cryogenics.2010.09.002

[16] Amini, K., Nategh, S. and Shafyei, A. (2010) Influence of Different Cryotreatments on Tribological Behavior of 80CrMo12 5 Cold Work Tool Steel. Materials \& Design, 31, 4666-4675. http://dx.doi.org/10.1016/j.matdes.2010.05.028

[17] Li, S.H., Xie, Y.Z. and Wu, X.C. (2010) Hardness and Toughness Investigations of Deep Cryogenic Treated Cold Work Die Steel. Cryogenics, 50, 89-92. http://dx.doi.org/10.1016/j.cryogenics.2009.12.005

[18] Barron, R.F. (1974) Do Treatments at Temperature Below $-120^{\circ} \mathrm{F}$ Help Increase the Wear Resistance of Tool Steels? Here Are Some Research Findings That They Do. Heat Treating, 14-17.

[19] Gill, S., Singh, J., Singh, R. and Singh, H. (2012) Effect of Cryogenic Treatment on AISI M2 High Speed Steel: Metallurgical and Mechanical Characterization. Journal of Materials Engineering and Performance, 21, 1320-1326. http://dx.doi.org/10.1007/s11665-011-0032-z

[20] Das, D., Dutta, A.K. and Ray, K.K. (2009) Optimization of the Duration of Cryogenic Processing to Maximize Wear Resistance of AISI D2 Steel. Cryogenics, 49, 176-184. http://dx.doi.org/10.1016/j.cryogenics.2009.01.002

[21] Das, D., Dutta, A.K. and Ray, K.K. (2009) Influence of Varied Cryotreatment on the Wear Behavior of AISI D2 Steel. Wear, 266, 297-309. http://dx.doi.org/10.1016/j.wear.2008.07.001 